\title{
How the journalist and the historian came to the environmental issues, $1964-1969$
}

In the course of the 1960s, the journalist Barbro Soller and the historian Birgitta Odén developed a deep involvement with environmental issues. As a result, their lives and careers moved to new paths. Soller took part in the establishment of a new journalistic field. Odén strove to do the same in the history discipline. However, their respective initiatives led to completely different results. Whereas Soller achieved success and renown, Odén encountered resistance that made her break off her attempts.

Barbro Soller and Birgitta Odén were prominent professional women at a time when such individuals were unusual. The worlds they worked in were dominated by men. In 1965, Dagens Nyheter employed 183 journalists. Only thirty of them were women. ${ }^{1}$ In November that same year, Odén became a professor at Lund University. All her colleagues and all her predecessors were men. Odén herself did not draw attention to her pioneering role, however. ${ }^{2}$ Nor did Soller. The two women operated through example and action rather than through debate and polemic.

As we have seen in the previous chapters, the big breakthrough of environmental issues in Sweden followed two different paths. One was apocalyptic and global; the other was more low-key and national. Soller and Odén were mainly active in the latter. While taking environmental destruction seriously, they did not talk about it as constituting a threat to human survival. Nor was their focus primarily on overpopulation or weapons of mass destruction. Tracking their actions therefore reveals somewhat different paths of development from those followed by Hans Palmstierna, Karl-Erik Fichtelius, and Rolf Edberg.

1 Anon., 'Ett väl sammansvetsat DN-lag', DN, 1 June 1965.

2 Eva Österberg, 'Birgitta Odén', in 2017 Yearbook (Stockholm: The Royal Swedish Academy of Letters, History and Antiquities, 2017), p. 28. 
My study of the two pioneering women begins with Barbro Soller's journalism. I follow her from the time she was hired as a general reporter in 1964 until she left Dagens Nyheter in the summer of 1969. During this period she became Sweden's first environmental journalist. But when did this happen, and how? And what role did she play in and for the breakthrough of environmental issues in Sweden? I then investigate how Birgitta Odén, in collaboration with the Swedish National Defence Research Institute (FOA), political scientists, and economists, developed the interdisciplinary project 'Miljö, naturresurser och samhälle' [Environment, natural resources and society]. I follow her from the time when the first steps were taken, in May 1967, until she abandoned the project in the spring of 1969. I also analyse how she worked at the local level to build up an environmental-history research speciality at the Department of History at Lund University. First, though, we will have a look at the late winter of 1964, when Barbro Soller shook up the Swedish biocide debate for the first time.

\section{General reporter and environmental journalist, 1964-1966}

On Saturday 22 February 1964, Barbro Soller reported that mercury had been detected in Swedish hen eggs. Dagens Nyheter made the news its lead story. The front page featured a photograph of the chief physician and associate professor Stig Tejning. Wearing a white lab coat and holding tweezers in his right hand, he peered gravely into the camera. The lead paragraph stated that unlike other animals, hens rarely became ill when fed mercury-treated seed. The hens' resistance posed a danger to humans: 'The mercury that the hens eat passes into the eggs we eat', said Soller. Inside the newspaper, she explained the procedure followed by Tejning and his colleague Ragnar Vestberg in detail. She was careful to let the researchers speak for themselves. ${ }^{3}$

The next alarm came on the following Friday. Soller reported that a new study showed that 'we Swedes also carry a dose of DDT in our body fat'. The findings came from Associate Professor Gunnar Widmark. The newspaper's front-page article explained that he was part of a large research group which had prepared a new proposal for Swedish biocidal research. The aim was 'to clarify the general situation and shed light on the ecological effects resulting from the

3 Barbara, 'Kvicksilver i svenska ägg', DN, 22 February 1964. 
use of chemical pesticides'. The application had been prepared by Bengt Lundholm, who emphasized that several of the sub-projects were 'of such a nature that they must be implemented immediately'. This was especially true of the issue of mercury poisoning. 'We cannot afford to lose another year', he stressed. ${ }^{4}$

What Soller reported on in February 1964 was not the result of scientific studies pursued for many years. On the contrary, she wrote about preliminary studies and applications which had emerged in the wake of the intense Swedish biocide debate in 1963. Through Soller, researchers were able to present preliminary results to the public and demand more research funding. In the weeks that followed, she wrote continuously about Tejning and Vestberg's new experiments. Among other things, their studies showed that the mercury accumulated in the egg white. The levels were much lower in the yolk, and there were no traces in the shell. ${ }^{5}$ The researchers also pointed out that hens which had eaten mercury-treated seeds did not lay their eggs in the nest boxes. This might, they said, account for Swedish birdwatchers' reports of nest failure among white-tailed sea eagles and other bird species. ${ }^{6}$

Barbro Soller's articles about environmental toxins attracted a good deal of attention at the time. They shifted the focus from Rachel Carson's Silent Spring to studies of Swedish conditions. The mercury-laden eggs were debated on editorial pages and discussed by representatives of various government authorities. Within environmental-history research, this has been taken as evidence that Soller became Sweden's first full-time environmental journalist in 1964..$^{7}$ Some nuance should be brought into that interpretation, though. At this time Soller was writing about all sorts of things, from choral singing and art exhibitions to foreign celebrities visiting Stockholm. ${ }^{8}$ She was certainly deeply committed to environmental issues; but she was a general reporter by profession. ${ }^{9}$

4 Barbara, 'Giftkontroll i stor skala', DN, 28 February 1964.

5 Barbara, 'Foderexperiment med höns. Mest kvicksilver i äggvitan’, DN, 9 March 1964.

6 Barbara, 'Värpning utanför redet kan förklara fågeldöd', DN, 11 March 1964.

7 Djerf Pierre, Gröna nyheter, p. 114.

8 Barbara, 'De tränar för konsertresa till Amerika', DN, 18 February 1964; Barbara, 'Tusen såg vårvernissage i DN-regi', DN, 9 May 1964; Barbara, 'Ungdom om Chrustjevs besök', DN, 25 June 1964; Barbara, 'Mera slagsmål med Floyd', DN, 2 July 1964.

9 The following is based on Larsson Heidenblad, 'The Emergence of Environmental Journalism'. 
This phase of her career lasted from 1964 until 1966. During this period, other topics she wrote about included Charlie Chaplin's visit to Stockholm and what lifeguards did at a west-coast seaside resort. ${ }^{10}$ One of her specialities was lengthy articles about animal and birdlife, usually published in the Sunday supplements and illustrated by colour photographs. These texts indicate her deep interest in nature, but they were hardly a form of environmental journalism. Their focus lay on the animals' lives and behaviour. There was no discussion of any environmental crises or toxins. ${ }^{11}$

Over time, though, Soller's position at Dagens Nybeter became more and more established. In the spring of 1966, she had the opportunity to make her first major reportage trip abroad. Together with the photographer Stig A. Nilsson, she travelled around India for a month to report on the looming hunger crisis. Dagens Nybeter marketed the article series in advance, and all three parts featured prominently on the front page. It is worth noting that the first part was published exactly one week after Hans Palmstierna's 'Malthus och världssvälten'. But whereas Palmstierna was a scientific debater, Soller was a journalist who painted pictures. She informed readers that it was a drought year in India. The ground was ulcerous and full of cracks. River beds had been transformed into burnt valleys, and the wells had dried up. 'The soil, humans and animals are thirsting as they have not done for a hundred years.' The reason was that the monsoon rains had not come, and harvests had failed throughout the country. India depended on help from the outside world. ${ }^{12}$

Soller stressed that 46 million of India's 480 million people were threatened by an acute food shortage. To ensure that aid reached them, the authorities built new roads and dams. These relief efforts gave poor families a chance to make a living. They could use their wages to buy food at fixed prices. Through texts and photographs, Soller and Nilsson gave faces to the humanitarian catastrophe. One of those depicted was a family man sitting with his back to his

10 Barbara, 'Kärlek vid första ögonkastet när Chaplin mötte "Vasa”', DN, 3 November 1964; Barbara, 'Åtta livräddare vaktar Tylösand', DN, 1 July 1966.

11 Cf. Barbara, ‘Älgar skyr moderlös kalv’, DN, 31 March 1965; Barbara, 'Orrtuppen kuttrar året om', DN, 18 April 1965; Barbro Soller, 'Bild av universum medfödd hos fågel', DN, 2 October 1966.

12 Barbro Soller-Svensson, 'Hungersnöd hotar 46 miljoner indier. Barn bygger "svältens väg”, DN, 10 May 1966. 
family. He had given his daily ration of bread and water to his wife and daughters. To avoid feeling hunger, he was looking the other way while they ate. ${ }^{13}$

The second part of the series criticized the way in which the Indian authorities were handling the crisis. Soller said that detailed maps of the famine had been drawn up. On them, it was possible to read what percentage of the population in an area had been affected by drought and crop failure. 'But if one reads the reality, one easily loses respect for the statistics', she wrote, and singled out a village which the maps claimed had been spared. The government sent purchasers there to buy hundreds of kilos of grain. But the villagers had no surplus. They therefore had to buy at a high price in the market and sell cheaply to the authorities. 'It is more than likely that the purchaser became blinded by the map statistics', Soller commented. In connection with the report, she interviewed India's minister of agriculture, whom she described as 'a feisty, energetic little man' with irrepressible optimism. His goal was to get Indian farmers to grow crops scientifically. This called for land reforms, tractors, new types of grain, chemical fertilizers, and chemical pesticides. The vision was that India would be self-sufficient by 1970. Soller was sceptical. ${ }^{14}$

The final part of the series dominated the Sunday edition on 15 May 1966. Dagens Nyheter wrote that the series of articles had aroused strong feelings in its readers. Many of them wanted to help. The paper therefore published a list of current and planned Swedish relief measures to which readers could donate money. ${ }^{15}$ Soller interviewed and portrayed Prime Minister Indira Gandhi, but without any critical edge. Gandhi was 'a person with a difficult job' who was doing it 'with true Indian dignity'. In their conversation, the two women discussed what the West could learn from India. ${ }^{16}$ The article about the ongoing population explosion was far more censorious. Soller stressed that India's population was growing by one million people a month, which she said was an untenable situation. All measures to improve people's living conditions 'will be eaten

13 Soller-Svensson, 'Hungersnöd hotar 46 miljoner indier'.

14 Barbro Soller-Svensson, 'Regeringen köper upp de fattigas "överskott”, DN, 12 May 1966.

15 Anon., 'Många möjligheter hjälpa "Det svältande Indien”', DN, 15 May 1966.

16 Barbro Soller-Svensson, 'Indira Gandhi - "en person med ett svårt job”, DN, 15 May 1966. 
up by the rising excess population', unless 'the measures are specifically focused on family planning'. So far, though, all campaigns had been ineffective. Despite the fact that over a million sterilizations had been carried out and 16,000 family planning centres had been set up, India's population had continued to grow with undiminished vigour. By the year 2000, the country would be home to an estimated one billion people. It was a frightening prospect. ${ }^{17}$

Barbro Soller's role in the article series 'Det svältande Indien' [Starving India] was that of the committed reporter. She had a personal style, and she did not hesitate to deliver criticism and draw her own conclusions. In this she was part of a larger trend. The 1960s saw a shift in the journalistic ideal, from objective mirroring to critical scrutiny. ${ }^{18}$ The shift occurred alongside the professionalization of journalism. Journalism colleges were established in Sweden in 1962, and in the course of the decade the ties between the political parties and the press weakened as well. These changes made a more independent journalistic role possible. ${ }^{19}$ That development turned out to be of great importance for Barbro Soller and for the breakthrough of environmental issues in Sweden.

After returning from India, however, Soller returned to being a general reporter for some time. She worked in this way for the rest of 1966. Her articles might just as easily be about holidaymakers in the Swedish coastal province of Bohuslän or the Oktoberfest in Munich as about new environmental warnings. ${ }^{20}$ However, her time as a generalist was coming to an end. That autumn she wrote an ever-increasing number of environmental and animal-focused articles, and from January 1967 onwards she wrote exclusively on those

17 Barbara, 'Hoppet står till spiralen', DN, 15 May 1966.

18 Monika Djerf Pierre and Lennart Weibull, Spegla, granska, tolka: Aktualitetsjournalistik $i$ svensk radio och TV under 1900-talet (Stockholm: Prisma, 2001).

19 Stig Hadenius and Lennart Weibull, Partipressens död? (Stockholm: Svensk informations mediecenter, 1991); Daniel Hallin and Paolo Mancini, Comparing Media Systems (Cambridge: Cambridge University Press, 2004); Lennart Weibull, 'Är partipressen död eller levande? Reflexioner från ett presshistoriskt seminarium', Nordicom-Information 35.1-2 (2013); Elin Gardeström, Att fostra journalister: Journalistutbildningens former i Sverige 1944-1970 (Gothenburg: Daidalos, 2011).

20 Barbara, ‘3600 turister i Smögenhem: Härligt vatten', DN, 4 July 1966; Barbro Soller, 'Bayrarna firar med fulla krus', DN, 29 September 1966; Barbara, 'Ny gifttyp i naturen: "Farligare än DDT"', DN, 23 November 1966. 
topics. Barbro Soller was now Sweden's first environmental journalist. In that role, she would once again make the topic of mercury in food front-page news.

\section{Barbro Soller and the mercury-laden pike 1967-1968}

On Saturday 21 January, Soller reported that high levels of mercury had been measured in Swedish lake fish. The discovery was made by Sweden's National Institute of Public Health, which was doing a national survey of fish stocks. Soller reported that the ongoing studies had yielded worrying results. In Sweden's largest lake, Lake Vänern, researchers had found northern pike with up to $1.4 \mathrm{mg}$ of mercury per kilo, far above the set limit value of $1 \mathrm{mg}$. The authorities therefore advised the public against eating Vänern fish every day. However, they stated as fact that people could 'consume fish from this and other mercury-contaminated watercourses once a week' without risk. Soller was critical. She pointed out that the limit values for other foods were set at $0.05 \mathrm{mg}$ of mercury per kilo. 'So why do you recommend a value for fish that is 20 times higher?' she asked. Professor Arvid Wretlind replied that fish accumulated mercury faster than land animals, so it was necessary to allow for a higher natural baseline value. There was no reason to panic, he stressed, because the average Swede ate such small amounts of fish. The new recommendation was only intended for people with an unbalanced diet featuring lake fish. ${ }^{21}$

Soller was not reassured, however. She monitored studies of Swedish lake fish closely, and her reports repeatedly appeared on the newspaper's front page. In mid-February 1967, a major meeting about mercury was held at the Government Offices in Stockholm. Acting together, the Ministries of Agriculture and Social Affairs had invited six researchers, including Stig Tejning. From the meeting, Soller reported that the mercury content in Swedish lake fish was nineteen times higher than that of sea fish. ${ }^{22}$ Suspicions fell on industry, and studies pointed the finger at the pulp mills. ${ }^{23}$ In March, she reported on Tejning's continued research into mercury-treated seeds. The studies showed that people who worked with mercury could be irreparably harmed. Soller argued that this evidence should

21 Barbara, 'Giftgräns för fisken i insjöar. Bara en gädda i veckan', DN, 21 January 1967.

22 Barbara, 'Varning för insjöfisk', DN, 14 February 1967.

23 Barbara, 'Ny giftkälla kartläggs', DN, 16 February 1967. 
be considered highly significant to 'the ongoing discussion about what mercury levels we should accept in fish for sale'. ${ }^{24}$

In parallel with Soller's mercury campaign, the Swedish survival debate had begun to gain momentum. Hans Palmstierna and KarlErik Fichtelius were regularly writing debate articles on Dagens Nyheter's culture page. Rolf Edberg's Spillran av ett moln was about to be printed in a third edition. In April, Soller's and Edberg's paths crossed. This was the first time that Sweden's ambassador to Norway had been interviewed in the Swedish press about Spillran av ett moln. The prominently placed article was presented as the launch of a new series of articles entitled 'Den hotade människan' [Endangered humanity]. Soller pointed out that Edberg's book had become a bestseller in scientific circles. In the interview, she took a back seat and allowed Edberg to present his case. He maintained that the prosperity of countries was often 'measured in the number of cars, televisions, and telephones'; but in his view, the degree of environmental degradation was a far more reliable measure of 'civilization'. He personally believed that prosperity should be measured in a different way: 'Air to breathe instead of poison to breathe. Water to drink instead of poison to drink.' Edberg's pointed statements were illustrated by a half-page colour photo of a rubbish tip..$^{25}$

The next day, a follow-up article appeared. Soller interviewed the professor of bacteriology Carl-Göran Hedén, a contributor to Människans villkor, who directed sharp criticism against the politicians and the political system. He said that more people with Rolf Edberg's clear-sightedness were needed. Humanity's most important issues required leaders with insight into the biological situation of the species. The problem was that today's politicians were only responsible 'to their voters and not to their voters' children and grandchildren'. Consequently, immediate and topical issues were prioritized over long-term threats. Hedén focused in particular on the population issues and the imminent global food crisis. Research, he felt, should concentrate on these issues in order to solve the general problems. Just as in her Edberg interview, Soller herself was almost invisible in the text. She asked brief questions which Hedén answered at length, and she did not express any criticism or personal

24 Barbara, 'Arbete med kvicksilver kan ge obotliga skador', DN, 4 March 1967.

25 Barbro Soller, 'Vi plundrar våra barns jord', DN, 9 April 1967. 
views. Her role in the article series was to ensure that the warning voices were heard. ${ }^{26}$

After the Hedén interview, however, no more articles were published in the 'Endangered Humanity' series. This fact says something about how Soller conducted her environmental journalism at this time. She moved quickly from topic to topic and did not adhere to any set plan. In the months that followed, she wrote about such topics as oil spills, conservationists in Skåne, the restoration of silted-up lakes, and the establishment of a new educational programme in environmental engineering. ${ }^{27}$ But the topic to which she consistently returned was the mercury content in Swedish lake fish. In the autumn of 1967, she intensified her coverage.

On Friday 13 October, Soller reported that people who ate large amounts of fish from Lake Vänern could suffer brain damage. Stig Tejning was again responsible for this alarm. He had examined 'the blood and hair of 54 extreme fish-eaters around Lake Vänern', mainly professional fishermen and their family members. On average, the group members had five times more mercury in their blood cells than a control group. Tejning stressed that the situation was extremely serious and that the fishing industry was at risk of being wiped out for reasons of national health. Commercial fishermen were facing an economic disaster. Through Soller, Tejning also expressed his hopes for additional funding so that his research work could continue. $^{28}$

In mid-October 1967, the National Institute of Public Health completed its major geographical survey. Soller maintained that it confirmed all suspicions. ${ }^{29}$ One month later, the National Swedish Board of Health and the National Swedish Veterinary Board met. They banned the sale of fish from about forty watercourses, but not from Lake Vänern. Soller scathingly described this decision as proof that Sweden was now the first country in the world not to follow the World Health Organization's recommended limits on

26 Barbara, “"Extrapoäng åt forskning om svälten”, DN, 10 April 1967.

27 Barbara, 'Sandhamn i uppror: Tjockolja förstör', DN, 17 May 1967; Barbara, 'Oro men ingen hopplöshet bland Skånes naturvårdare', DN, 28 May 1967; Barbara, 'Lortsjö föryngras med tusentals år: Gyttja pumpas ut', DN, 26 June 1967; Barbro Soller, 'Miljöingenjör “bristyrke”: Räddar luft och vatten', DN, 11 September 1967.

28 Barbro Soller, 'Vänerfisken kan orsaka hjärnskada: Docent slår larm', DN, 13 October 1967.

29 Barbro Soller, 'Kvicksilvret i svensk fisk kartlagt', DN, 18 October 1967. 
mercury content in human food. ${ }^{30}$ In the following months, Soller reported on public debates. She also began writing editorials on the issue, ${ }^{31}$ arguing that the set limits were arbitrary and the sales ban had to be extended. She put pressure on the authorities by means of questions and articles.

On Saturday 3 February 1968, Soller triumphantly reported that 'the National Swedish Board of Health admits it was wrong about toxic values in Swedish lake fish'. The set limit value only applied if someone ate fish just once a week (something Soller had in fact reported a year earlier). However, this information was missing from the material that the National Swedish Veterinary Board had sent out to the country's municipal health boards. Therefore, Soller was now taking matters into her own hands. With her article, she wanted to tell the Swedish people the facts. On her side she had researchers and environmental debaters such as Stig Tejning and Hans Palmstierna. ${ }^{32}$ The close collaboration between the environmental journalist Soller and parts of the scientific research community was characteristic of the breakthrough of environmental issues in Sweden. Affording the researchers voice and publicity, she also pursued an increasingly independent and critical approach towards certain authorities and the researchers who worked for them. Her position at Dagens Nyheter was strengthened, and the opportunities for her to conduct investigative journalism increased.

\section{Nya Lort-Sverige 1968-1969}

Barbro Soller's big public breakthrough as an environmental journalist came in the spring of 1968 with the reportage series 'Lort-Sverige 30 år efteråt' [Filth-Sweden 30 years later]. The title was a reference to Ludvig ('Lubbe') Nordström's social reportage Lort-Sverige of 1938, a Swedish classic which had shown how poor people in 1930s Sweden were living in dirty, draughty homes with bedbugs, fleas, and cockroaches. The reportage shocked contemporary society and became a driver of Social Democratic reform

30 Barbro Soller, 'Fisk i 40-tal vatten otjänlig människoföda trots höjd giftgräns', DN, 15 November 1967.

31 Barbro Soller, 'Kvicksilverexpert slår larm: Förgiftad fisk kan ge allvarliga fosterskador', DN, 26 November 1967; Barbro Soller, 'Kvicksilverutsläppen vållar miljonförluster', $D N, 9$ December 1967.

32 Barbro Soller, 'Folkhälsan medger fel om giftvärdena för insjöfiskarna', $D N$, 3 February 1968. 
policy. By 1968, however, Nordström's Filth-Sweden was history: within thirty years, Swedish homes had become clean and modern. But Soller claimed that this progress had a dark side. The dirt had not in fact disappeared at all. It had just been moved out into the natural environment. ${ }^{33}$

'Lort-Sverige 30 år efteråt' was the outcome of new collaboration between Soller and the photographer Stig A. Nilsson. In the spring of 1968 they travelled around Sweden, just as they had travelled around India two years earlier. Together, they revealed and investigated a variety of unsatisfactory conditions. All seven articles featured prominently on the front page of Dagens Nyheter, occasionally accompanied by colour photographs. Each part began by quoting a passage from Nordström's 1930s report and comparing it with the present. Soller placed particular emphasis on the environmental consequences of modern comforts such as cars, flush toilets, washing machines, and dishwashers. Among other things, she portrayed a family with small children in Värmland and asked the National Swedish Institute for Building Research to calculate the environmental impact of their life in a modern house.

In the article, Soller alternated freely between different styles. She wrote in the form of a fairy tale about how the young family had left their cramped apartment to move into their new house. It was 'a very common tale in 1968', she emphasized; 'all over the country, women and men rejoiced at the advance of technology in kitchens and bathrooms'. The machines made life easy and clean. 'But all good fairy tales contain a troll, or at least a dismal chapter', she added. So did the fairy tale about modern Swedish life in a house. She then switched to an objective tone and described how the family was indirectly polluting the water, land, and air. She gave precise figures and compared them with the situation thirty years earlier. The trend was worrying. Soller therefore appealed to her readers not to use phosphate-laden laundry detergent or install kitchen waste-disposal units. 'We are all involved in creating the environment we live in', she wrote, 'but we can improve it, and great efforts are being made to reduce everyone's contributions to the total mass of pollution.' She looked ahead with hope to a society where rubbish would become valuable compost and not air pollutants. $^{34}$

33 Barbro Soller, 'Nya Lort-Sverige synas av DN: Avloppsslam på avvägar', DN, 26 March 1968.

34 Barbro Soller, 'Hög standard smutskälla', DN, 11 April 1968. 
Another report in the series focused on Stockholm's urban air. The front page featured a picture of a man from the city health board. He was holding a sheet of originally white paper that had been stained black by exhaust fumes. Behind him was a mass of cars. Thirty years earlier, Soller said, there had been about 60,000 motor vehicles in Stockholm. By 1968 the figure was 360,000. Car exhaust fumes mingled with the chimney smoke from oil boilers, district heating plants, and factories. The best protection against the Stockholm air was to cough.

Soller explained that many people had become accustomed to the gradual deterioration in air quality. Others protested, however. She described how a growing group of inner-city parents had begun to lobby the politicians. The parents did not want their children to have to grow up in an environment that harmed their health. They therefore demanded an immediate ban on lead in petrol, the implementation of mandatory catalytic converters, and the revocation of plans for new multistorey car parks in the city centre. Soller predicted the formation of an 'increasingly vigilant opinion'. ${ }^{35}$ In the spring of 1968 , she herself was very much involved in the creation of that opinion.

The 'Filth-Sweden 30 years later' series of articles also contained reports about agriculture and industry. Soller contrasted the sanitary problems of lice and flies in the Swedish homes of the 1930s with the widespread use of chemical pesticides in the 1960s. She had been involved in biocide issues for a long time and had good contacts with the world of research. But in the spring of 1968, she applied a journalistic approach that was new in this context: she appealed directly to farmers. What did the people who grew and sprayed the crops really think?

The small-scale farmer Gösta Olsson in Skåne replied that, like many others, he had subcontracted his spraying to an agricultural service-supply agency - 'today's new farmer'. The year before, though, he had stopped using mercury-treated seed on his own initiative and still had a good harvest. Soller said that Olsson was not alone in taking matters into his own hands. During the 1966-1967 season, the Seed Testing Institute had found that only one-third of the Swedish hay and grain crop required treatment, and only 40 per cent of that third was actually treated. In Soller's words, the farmers had 'begun their silent opposition to seed treatment, having become

35 Barbro Soller, 'Mest koloxid vid trafikljus i rusningstid', DN, 4 April 1968. 
increasingly aware that there might be consequences that would be hard to grasp'.

The next person she turned to was Henning Randau, director of one of the country's largest agricultural service-supply agencies. $\mathrm{He}$ was responsible for controlling weeds and pests on about 6,000 hectares of arable land in north-western Skåne. The newspaper's front page featured a picture of him wearing a full protective suit, gas mask, and gloves. In front of him stood drums of poison, and behind him the fields stretched out. He told Soller that the individual farmer could no longer keep up with developments. There were 700 to 800 chemical treatments on the market, and the equipment was expensive. As a result, agriculture had become increasingly large-scale and industrial.

Randau, however, did not become a target for criticism. On the contrary, he appeared responsible and forward-looking. He told Soller that new organic herbicides, equally effective but less toxic and easier for nature to break down, were in the process of replacing DDT. Besides, he expressed disapproval of the fact that no training was required to handle poisons. Many managers and sprayers working for agricultural service-supply agencies had only completed a short three-day course. Randau felt that that training did not amount to much. He held up the course textbook, Kemiska bekämpningsmedel [Chemical pesticides], the contents of which he claimed only trained chemists were able to comprehend. To young farm workers it was more confusing than clarifying. But then, there was no one with any hands-on experience on the national Poisons Board. 'When did the board last see a field?', Randau demanded. ${ }^{36}$

The last part of the reportage series focused on the pulp industry in Sundsvall in northern Sweden, where the country's largest forestryindustry company, Svensk Cellulosa AB (SCA), operated. Soller described how Ludvig Nordström had been impressed by the factory chimneys billowing smoke when he came to Sundsvall in the 1930s. To him, this was proof of industrial progress. To Soller, by contrast, it was a hugely polluting production process. She reported that SCA was using the sea to get rid of mercury and fibre mass without considering the long-term environmental consequences. Only in recent years had purification measures begun to be implemented. But much remained to be done. ${ }^{37}$

36 Barbro Soller, 'Bondens tysta motstånd: Obetat utsäde går lika bra', $D N$, 6 May 1968.

37 Barbro Soller, 'Ett “Lort-hav” vid Sundsvall', DN, 19 June 1968. 
The next day, Dagens Nybeter's lead editorial discussed Barbro Soller's reportage series. The writer stated that she had drawn 'a very dark picture' of the current state of environmental protection. Many of the small advances, such as the establishment of treatment plants, were only illusory improvements. In the course of her journey Soller had not found a single sewage-treatment plant that worked as it should. The editorial writer stated that the increasingly intense environmental debate of recent years had made people aware of the nature and extent of the problems. But what had those insights really led to? Only a small part of the environmental destruction was due to negligence and ignorance. The main reason was something else: it was economically profitable to pollute, and using poisons was cheap. 'We all receive a small pay-off via food prices', said the writer. The situation required sweeping changes. The new environmental awareness had to lead to 'a new willingness to take economic responsibility'. Through increased prices, fees and taxes, and reduced profits, everyone could help clean up Filth-Sweden. ${ }^{38}$

In the spring of 1968, Barbro Soller's reportage series reached Dagens Nyheter's many readers. The following year, her readership expanded further when her reportage was published in a revised and expanded form as a paperback publication entitled Nya-Lort Sverige [New Filth-Sweden]. The book was abundantly illustrated by Stig A. Nilsson's black-and-white photographs, which formed visual evidence of what Soller described. The introduction stressed its documentary approach. Soller emphasized how she had 'seen, smelled, heard, and coughed' her way through the new Filth-Sweden. With her book, she wanted to spread information and create debate, and she hoped it would contribute to 'a faster resolution of difficult issues'. The environmental problems 'are difficult', she emphasized, but 'in Sweden we can afford to make an effort to fix them'. There were great opportunities to become a pioneering nation, a nation which would be able to help other countries 'where resources have been consumed and worn down even worse than here at home'. ${ }^{39}$

Soller's book Nya Lort-Sverige received favourable reviews and appeared in a second edition in 1970. Concurrently with its publication, Soller and Nilsson made one last major reportage trip together. It resulted in the article series 'Djurfabriken' [The animal factory], which was an in-depth investigation of the Swedish meat industry. The series

38 Anon., 'Lort och pengar', DN, 20 June 1968.

39 Barbro Soller, Nya Lort-Sverige (Stockholm: Rabén \& Sjögren, 1969), p. 8. 
ran from March to June, but it was not at all marketed - or attracted attention - in the same way as 'Filth-Sweden 30 years later'. For example, only the first part of the series was featured on the front page. This reportage series would mark the end of Barbro Soller's years at Dagens Nybeter. In the summer of 1969, she left the newspaper to work elsewhere. Her career as an environmental journalist was not over, though; in 1972 she was hired by Swedish Television to build up the television news department's environmental coverage. ${ }^{40}$

The big breakthrough of environmental issues which occurred in late 1960s Sweden was also a personal breakthrough for Barbro Soller herself. Through her journalism she merged science with everyday life. In the public media arena she was a unique knowledge actor who fulfilled many different functions. At first, her chief role consisted in providing scientific researchers with a voice and public attention. In her role at Dagens Nyheter she could make knowledge circulate and ensure that researchers' warnings were taken seriously. Over time, she personally gained an ever stronger and more independent position. It was she who saw to it that mercury-laden pike and the new Filth-Sweden ended up on the front pages.

Even so, the breakthrough of environmental issues in Swedish society did not only occur in the media limelight. Many of the people involved in the issues operated in other types of arenas. One of those individuals was the newly created professor of history Birgitta Odén. Through her archive of documents and supplementary interviews, I have been able to reconstruct how she tried to build up a new field of environmental history research in the late 1960s. ${ }^{41}$ She did so at a time when there was no self-aware environmental history research field anywhere in the world..$^{42}$ Odén's ambition was

40 Djerf Pierre, Gröna nyheter, pp. 215-222.

41 The following is based on Larsson Heidenblad, 'Miljöhumaniora på 1960-talet?'

42 The origin of the environmental history field is usually dated to 1972 , when a special issue of Pacific Historical Review was published. See Roderick Nash, 'American Environmental History: A New Teaching Frontier', Pacific Historical Review 41.3 (1972). For historiographical overviews see Richard White, 'American Environmental History: The Development of a New Historical Field', Pacific Historical Review 54.3 (1985); William Cronon, 'A Place for Stories: Nature, History, and Narrative', Journal of American History 78.4 (1992); Richard Grove, 'Environmental History', in Peter Burke (ed.), New Perspectives on Historical Writing, 2nd edition (Cambridge: Polity, 2001; first edition 1991); J. Donald Hughes, What is Environmental History? (Cambridge: Polity, 2006); Franz Bosbach, Jens Ivo Engels, and Fiona Watson, 
to make the academic study of history more socially relevant and to help politicians make better decisions. But why was it that she, who until the mid-1960s had devoted herself to the state finances of sixteenth-century Sweden, wanted to tackle one of the burning issues of her day? What did she believe historians could contribute? And how did she go about building up a new field of research?

\section{Two meetings at the Defence Research Institute, 1967}

The origins of Birgitta Odén's environmental-history initiative can be found at the Swedish National Defence Research Institute (FOA). In the spring of 1967, the Institute had begun to discuss environmental issues in terms of security policy. Behind this move was Martin Fehrm, the director-general and head of FOA. At this time he was also chairman of the Swedish Natural Science Research Council, and he was one of the members of the ongoing commission of enquiry into natural resources. Fehrm had an idea that the models for systematic planning for the future that had been developed by FOA in the military field might also be put to use in the field of environment and natural resources. The realization of that idea called for social-science knowledge and expertise, however. In May 1967, he therefore invited three professors to a meeting at FOA: the political scientist Pär-Erik Back, the economist Assar Lindbeck, and the historian Birgitta Odén.

At this stage, there were no plans for a joint research project. Fehrm was primarily interested in testing established systems-theory planning techniques in the environmental field. This required socialscience data plus knowledge of political decision-making processes. The three professors, though, explained that the material he wanted was not available. No relevant research had been done in political science, economics, or history. In order for systematic planning for the future to be possible, new research efforts were hence required. ${ }^{43}$

In the meeting, participants discussed whether they should join forces and write a debate book. They wanted such a book to make

Umwelt und Geschichte in Deutschland und Grossbritannien (Munich: K. G. Saur, 2006); Fabien Locher and Gregory Quenet, 'Environmental History: The Origins, Stakes and Perspectives of a New Site of Research', Revue d'Histoire Moderne et Contemporaine 56.4 (2009).

43 Birgitta Odén, 'Projektet Natur och samhälle', in Lars M. Andersson, Fabian Persson, Peter Ullgren, and Ulf Zander (eds), På historiens slagfält: En festskrift tillägnad Sverker Oredsson (Uppsala: Sisyfos, 2002), pp. 317-318. 
politicians and the general public aware of the seriousness of the ongoing environmental destruction. The idea was that the book would culminate with a plea for major investment in targeted research activities. No decision was made, however, and the next meeting at FOA was not held until 27 November 1967. At this second meeting Birgitta Odén played a decisive role, because she had been given the task of compiling three memoranda on how the work should proceed. ${ }^{44}$

In these memos, Odén started out from the overall visions which Fehrm had presented in a memorandum that had circulated internally within FOA. There Fehrm stressed that meaningful and rational social planning required each decision to be made 'with the best possible knowledge about the consequences of the decision, but also and primarily with a clear specification of what the decision is meant to achieve'. The first step in the decision-making process was therefore to establish the relevant objective, evaluation criteria, and restrictions. ${ }^{45}$

The next step in the process was to identify and study the existing options for action. This would be done through plans and programmes in which costs and consequences were specified. The importance of 'hard-to-determine factors' and 'areas of uncertainty' would be highlighted, and a key role would be assigned to targeted research efforts. The aim of this research was to provide 'improved support material for future decision-making'. Birgitta Odén underlined this phrase in Fehrm's memo, and in the margin of the paragraph she noted: 'This is the only thing that history can be included in. ${ }^{46}$

Odén's marginal note is explained in another document where she wrote down her views of Fehrm's memo. There she writes that 'everything in Fehrm's plan deals with forecasts. For this, history is useless'. What she believed that historians could contribute was 'knowledge about how society has worked - and works' in relevant respects. ${ }^{47}$ She was ready to tackle the past and the immediate present, but forecasts did not appeal to her. Her marginal notes foreshadowed the frictions that would arise between FOA and the group of researchers.

44 This is evident from Birgitta Odén, 'Min föredragning', November 1967, BO 1.

45 Martin Fehrm, 'Välfärdssamhällets planerings- och beslutsfunktioner', November 1967, BO 1.

46 Fehrm, November 1967, BO 1.

47 Birgitta Odén, 'Mina synpunkter på Fehrms PM', November 1967, BO 1. 
The November meeting was primarily a constitutive meeting, though, and Odén began her presentation by explaining why a working group was now being formed. She maintained that 'we are all deeply concerned about the consequences of the development of technology and prosperity' and underlined that the discussion could not be restricted to the scientific and technical aspects of the environmental problem complex. It was equally important to equip politicians with studies 'concerned with the economic-social-political side of the matter'. She pointed to three paths forward for the group: the writing of a joint publication, the drafting of a research programme, and the establishment of the group as a coordinating body. To be sure, the last-mentioned job required 'a mandate directly from the government'; but this item in her memorandum was not brought up for discussion. ${ }^{48}$

In connection with the proposals, Odén listed a number of topics for discussion: the group's qualifications, composition, funding possibilities, and relationships to various authorities. A more complex point of discussion on the meeting agenda was the question of whether the group should write a joint publication. Odén posed the question of whether the situation really called for one: 'Or has the situation changed after the DN debate, Palmstierna's book, the report of the commission of enquiry into natural resources, and the actions of the National Environment Protection Board? ${ }^{49}$ The question reveals the degree to which Odén and the FOA group's work was abreast of current affairs, and it shows how the Swedish environmental debate had been fundamentally reshaped within the space of six months. Knowledge and crisis insights no longer circulated in specific circles only, such as those at FOA, but were now moving with great intensity within the public sphere.

Birgitta Odén's second memorandum did function as a springboard, however. It was a discussion paper on how an interdisciplinary research programme should be initiated. The memo argued that 'the existing scientific data indicate that we are facing a critical point in the development of society'. The study of environmental problems could therefore 'not be limited to a scientific investigation'. What was required was an 'integrated research programme', which would consist of a scientific-technological part and a social-scientific part. She underlined that cooperation between these fields was

48 Birgitta Odén, 'PM 3', November 1967, BO 1.

49 Birgitta Odén, 'Min föredragning', November 1967, BO 1. 
'[the whole] point of the group's consolidation'. The stated goal was to provide politicians with an improved basis for decisionmaking. ${ }^{50}$

The prerequisites for 'an investment with maximum return' were the central focus of Odén's second memorandum. She especially stressed the importance of the fact that the group considered 'the goal sufficiently important to want to make a personal commitment and guide younger researchers who are working in the programme'. As we shall see, she herself put this goal into practice. She also felt that some form of authorization, an administrative management team, and adequate financial resources were required. Besides, in order for the relevant social-science research to be meaningful, general permission was needed to study 'the archival material of the civil service and the ministries'. ${ }^{51}$ The November meeting concluded with those present deciding to proceed with the interdisciplinary initiative.

\section{Discord between the researchers and FOA}

The third meeting at FOA took place in February 1968. Beforehand, someone - it is unclear who - compiled a work plan for the group. The plan stated that 'the group's task was to create a new model for values in social planning by transferring systems-theory analysis used within FOA to the social sector'. However, constructing this model needed to be preceded by a research stage which would focus on 'the role of values in the decision-making process, the availability of relevant knowledge at various decision-making levels, and the relationship between the decision-making organizations' values and those of various opinion groups'. In order for the research task to be manageable, it was limited to environmental issues. ${ }^{52}$

Six disciplines supplied points of entry into the outlined research programme: science, technology, medicine, economics, political science, and history. Svante Odén and Hans Palmstierna, as well as technical experts working at FOA, were responsible for supplying the expertise in the first three areas. The coordination required extensive planning in close consultation with 'the envisaged recipients' of the findings. This concept primarily referred to the two directors-general: Valfrid Paulsson at the National Environment Protection Board and Martin

50 Birgitta Odén, 'PM 2', November 1967, BO 1, p. 1.

51 Ibid.

52 'Arbetsplan för gruppen på FOA', February 1968, BO 1, p. 1. 
Fehrm at FOA. ${ }^{53}$ Alongside the work plan, a slightly revised version of Fehrm's memorandum 'Välfärdssamhällets planerings- och beslutsfunktioner' [The welfare society's planning and decision-making functions] was also being circulated. It stressed the importance of maintaining 'the biological balance', and that environmental destruction must not be permitted to jeopardize future generations' room for manoeuvre. ${ }^{54}$

The level of ambition for the research programme was unmistakeably high. At the same time, the work plan did not provide any concrete guidance as to how the group should move from planning to research. In conjunction with the meeting at FOA, Birgitta Odén noted that various vested interests had begun to emerge, and that group members were therefore pulling in different directions: scientific research; social research; research policy and organization; and forecasting activities. To resolve the contradictions, she felt that the research programme's recipient - the National Environment Protection Board - should rule on what was desired, and then the group could be reorganized in accordance with that goal: 'it is up to each individual participant to organize that which is left over'. However, she perceived an imminent risk of 'a fragmentation of the group'. ${ }^{55}$ The alternative was clear guidelines and a focusing of the research efforts. On the back of the paper, she wrote that the people who should make the relevant decisions were Valfrid Paulsson and Martin Fehrm, because they had 'the [necessary] contacts with the politicians'. ${ }^{56}$ However, she crossed out this whole paragraph. Judging from other documents, it also seems that Odén was not prepared to be dictated to by FOA.

The clearest proof of this can be found in a letter dated 20 February 1968 to Erik Dahmén, professor of economics at the Stockholm School of Economics. The purpose of Odén's letter was to bring about an informal meeting on 5 March. Dahmén had been informed about the FOA group's work on environmental issues via Assar Lindbeck and Svante Odén, and they had invited him to participate. A scholar with a special interest in environmental issues, Dahmén was completing the debate book Sätt pris på miliön [Put a price on the environment] at this time. ${ }^{57}$ In her letter to Dahmén,

53 'Arbetsplan för gruppen på FOA', pp. 1-2.

54 Martin Fehrm, 'Välfärdssamhällets planerings- och beslutsfunktioner', February 1968, BO 1.

55 Birgitta Odén, 'Mitt PM för 15/2 FOA', February 1968, BO 1, p. 1.

56 Ibid., p. 2.

57 Dahmén, Sätt pris på miljön. 
Odén explicitly writes that 'those of us who represent researchers outside FOA currently feel a great need to handle the assignment together and without FOA's involvement'. ${ }^{58}$

The informal meeting was duly held at the Stockholm School of Economics, but neither Dahmén nor Back was able to attend. However, Svante Odén was present, which shows that the dividing line went between the research group as a whole and FOA. ${ }^{59}$ In a letter to Back, Odén expresses relief that the group has begun to take the practical planning work into its own hands. Her letter raises the issue of whether the contacts with FOA should perhaps be limited to collaboration with chief engineer Erik Moberg, who also 'does not want to toss this out quickly, but feels we should work on the matter for a couple of years' ${ }^{60}$ She concludes by saying that the whole situation had finally reached a state that felt reassuringly calm to her. Odén's letters indicate that the research group and FOA were working with different time perspectives. Martin Fehrm wanted quick results; the researchers wanted plenty of time.

\section{Environmental history in Lund with a political focus}

In parallel with the planning work at FOA, Birgitta Odén launched her own local initiatives. The first person she involved was Sverker Oredsson. At this time, Oredsson held a licenciate's degree and was completing his doctoral dissertation on Swedish railway policy in the nineteenth century. ${ }^{61} \mathrm{~A}$ central theme of that policy was debates about the common good and the individual good. This theme also appeared in another area: the nineteenth-century forest issue. Odén encouraged Oredsson to explore this further, and in September 1967 he wrote a three-page memorandum entitled 'Miljövård och politik under 1800-talet' [Environmental protection and politics during the nineteenth century]. The memorandum supplies a brief account of the relevant laws, committee work, and political debates. Among other things, Oredsson pointed out that an investigation from 1868 had concluded that 'the destruction of forests contributed to the

58 Letter from Birgitta Odén to Erik Dahmén, 20 February 1968, BO 2.

59 Letter from Birgitta Odén to Assar Lindbeck, 22 February 1968, BO 2.

60 Letter from Birgitta Odén to Pär-Erik Back, 22 February 1968, BO 2.

61 Sverker Oredsson, Järnvägarna och det allmänna: Svensk järnvägspolitik fram till 1890 (Lund: Rahm, 1969). 
severe crop failure in the late $1860 \mathrm{~s}^{\prime} .{ }^{62}$ The sentence was underlined by Odén. Possibly she saw it as a warning - and hence useful historical example.

The next piece of evidence to the effect that Odén had begun to involve her colleagues and students dates from February 1968. At that time, she sent a report to the National Environment Protection Board about planned and ongoing activities in Lund. The plan for doing basic research consisted of three parts: trend analysis, analysis from a history-of-ideas perspective, and opinion analysis. Responsibility for the first part rested with Sverker Oredsson, who was to deal with the political handling of the forest, water, drainage, and sewage issues during the period from 1850 to 1950 . The history-of-ideas analysis of the nature-and-environment issue from 1890 to 1950 would be carried out by Ingrid Millbourn, who held a master's degree, and the opinion issues would be investigated by Associate Professor LarsArne Norborg. In addition, Odén informed the National Environment Protection Board that the team intended to conduct 'targeted, interdisciplinary research' into selected political decisions about natureconservation issues and their effects on society. This work would be performed in collaboration with systems-analysis expertise.

The report also shows that the licentiate's-degree student Yvonne Bengtsson had started to explore the forest debate of the 1850s, and that four bachelor's-degree students had begun graduation-essay projects. The topics of their essays were the Conservative Party and the Shoreline Protection Act; Rachel Carson's Silent Spring and its reception in Swedish professional circles; Mörrumsån River and its problems; and the 1949 Forestry Act and the 1956 discussions. ${ }^{63}$ The students were not named in the document, but it is clear from these topics - and the fact that the essay titles were explicitly mentioned in her communication with the National Environment Protection Board - that Odén considered students' essay-writing to be an integral part of the broader research project. She built up the local programme by guiding students and young researchers towards environmental-history themes.

One of the people whom Odén managed to steer in this direction was Lars J. Lundgren. He had become a teaching assistant in 1967, and shortly afterwards was encouraged to begin working towards

62 Sverker Oredsson, 'Miljövård och politik under 1800-talet', 27 September 1967, BO 1.

63 Birgitta Odén, 'Redogörelse', 20 February 1968, BO 1. 
a doctorate. However, the choice of dissertation topic was not selfevident. The only thing he was sure of was that he did not want to pursue anything he had done before. Odén felt that Lundgren should take his time deciding, because he would be doing the work for many years. She believed it was not enough for the project to be interesting in purely scholarly scientific terms; the student had to feel for the subject and really want to explore it. Her exhortation led to a period of indecision before she requested a talk with him. When I interviewed him in 2017, Lundgren had clear memories of that discussion.

Odén began the conversation by saying that she had understood he was interested in current politics, modern music, and other contemporary topics. 'You seem to live quite a lot in the present', she said, 'and yet you are also a historian.' Lundgren agreed, whereupon Odén wondered if he might perhaps explore some current issue and its historical roots. Then 'she herself actually suggested this topic of the environment', employing the argument that 'you're out and about in nature so much, you should be interested in the environment'. The conversation aroused Lundgren's interest. $\mathrm{He}$ had followed the ongoing environmental debate, 'but never thought about it historically' ${ }^{64}$ Lundgren began to investigate the government commissions of enquiry and quickly realized that he was on the trail of his dissertation topic.

The conversation took place sometime in early 1968, and in the archival material Lundgren's name is mentioned for the first time in the project plan 'Natur och samhälle i svensk politik 1850-1967' [Nature and society in Swedish politics 1850-1967]. The plan, dating from February 1968, is in the form of an application to the statefunded Humanities Research Council. Because the application text is incomplete, and because subsequent documents refer to it as a memorandum, it was probably never submitted. The research plan shows that Odén was working along two distinct but intertwined lines at this time. On the one hand, she was preparing delimited research projects; on the other hand, she was involving young researchers so as to make them take these projects on. Her own role was that of research leader. There was no suggestion that she would do any empirical work herself. ${ }^{65}$

64 Interview with Lars J. Lundgren, 18 September 2017 (the recording is in the author's possession).

65 Birgitta Odén, 'Forskningsprojektet Natur och samhälle i svensk politik 1850-1967', February 1968, BO 1, pp. 4-7. 
The aim of the planned historical research programme was 'to gain knowledge about the major lines of development within the set of problems concerned with nature and society over the past hundred years'. Particular emphasis was placed on how 'attitudes and values have evolved with regard to the obligations and rights of individuals towards society - and vice versa - in terms of natural resources and environmental problems'. ${ }^{66}$ The two most extensively developed sub-projects were Sverker Oredsson's trend analysis of the forest issue and Ingrid Millbourn's history-of-ideas study of the political parties' ideological positions over the natural-resource issue from 1900 to 1930. Analysis of ideology formed a central approach in both projects, and Odén planned several similar studies, including one on the parties' positions from 1930 to 1960 and one that would address the contemporary (1960s) state of affairs. The third main area of the research plan, the development of opinion, also focused on the analysis of concepts and ideology. This area encompassed a study of the natureconservation associations' opinion-forming activities and another of press opinions on the nature-conservation issue during the 1960s. In addition, there were sketches of socio-historical studies of members of nature-conservation associations and of whether increased leisure time led to a greater interest in nature conservation. ${ }^{67}$

In addition to the concrete project descriptions, the application text contains a three-page general introduction. Odén began it by referring to pre-industrial Sweden, where 'collisions between nature and society' had been 'relatively small and insignificant'. People had essentially lived within the framework of nature, and 'care for future generations was part of the world-view', among other things with regard to the management of forest resources. She emphasized, however, that even in the past there had been 'overexploitation of natural resources with catastrophic effects'. The ethical example above others was the classical Mediterranean world, whose soils had been depleted as a result of 'overly intensive grazing and forest destruction'. She underlined that this devastation was not due to a 'short-term scale of values' but rather to 'scientific ignorance about the long-term consequences'. In Odén's view, this example of naturalresource abuse and environmental destruction showed how important it was that 'cluelessness about the relationship between nature and society' should be dispelled.

66 Ibid., p. 4.

67 Ibid., pp. 4-7. 
In industrialized society, this aspect was more important than ever before. It motivated the project's focus on modern history and its interest in ideologies, values, and political decision-making processes. Odén particularly stressed that 'the prosperity ideology's doctrine about the social and economic blessings of increased consumption' was insufficient because it did not take account of external effects on the environment. She argued that the unfavourable consequences of this neglect 'had only now become evident', and that it was therefore important to investigate how we had put ourselves in this situation. Had there been a lack of scientific information? Had political values been too short-sighted? What had the decision-making processes really looked like? ${ }^{68}$

These questions demonstrate that Odén attached decisive importance to political action. It was through political values, plans, and decisions that historical development was shaped. In line with these assumptions, historical research could benefit society by improving the basis for political decision-making. Research was particularly warranted in the environmental and natural-resource field because there the state of knowledge was so meagre. Odén believed that the reason for this was 'a phenomenon that does not appear to be interesting in the present and that was not perceived as interesting in past society either, [and has hence] not been felt to be immediately appealing as a research topic'. This state of things had changed thanks to the breakthrough of knowledge in society that had taken place in 1967. It was therefore important for historians to move into this new field, a field where their research was actually in demand. Socially beneficial historical research could not turn its back on the present: Odén felt that it should tackle and historicize current problems. ${ }^{69}$

\section{Planning work intensifies}

In March 1968, planning work entered a more intensive and more focused stage. The four professors involved - Odén, Back, Lindbeck, and Dahmén - had close contacts with one another and began to work seriously towards a common goal: a project application to the newly established Bank of Sweden Tercentenary Foundation, Riksbankens Jubileumsfond [now known under the latter name

68 Ibid., pp. 1-3.

69 Ibid., pp. 1-3. 
only]. ${ }^{70}$ The practical work took place without FOA's participation, but there was no formal rupture. On the contrary, the professors applied to FOA for SEK 20,000 each (approximately SEK 170,000 in today's money) to launch their respective research activities. The applications were approved in April, and Odén used her funds to pay the hourly wages of some of the young researchers she had brought into the project. These scholars were commissioned to perform limited tasks that were of importance to the overall design of the research.

Two of these people were Hans Idén and Ingemar Norrlid, who together took a course in systems-theory analysis. In addition, they extracted excerpts from secondary sources in systems theory in order to investigate whether the method had previously been applied in practical nature-conservation policy. Another individual who became involved in the overall scheme was Kerstin Malcus. Through studies of relevant secondary sources, she would focus on the issue of the classical instances of natural destruction and familiarize herself with the environmental-history discussions that were going on in the United States. At the beginning of May, it was also clear that Lars J. Lundgren's research work had begun to gain momentum. He was funded to review secondary literature as well as printed primary sources dealing with the historical development of the water-and-sewage issue and the question of drainage. Furthermore, Arne Fryksén examined changes to the Nature Conservation Act during the 1950s, and Bo Huldt reviewed how the Riksdag handled the matter of the Baltic Sea. ${ }^{71}$

In early April Odén contacted Paul Lindblom, director of the Bank of Sweden Tercentenary Foundation. He replied that the Foundation was 'swamped by applications' and was therefore not prepared to make a decision about the group's plans until October. On the other hand, the Foundation would have greater financial resources to operate with at that point. However, because the application had to be considered by various consultation bodies, it

70 For an overview of the early history of the Bank of Sweden Tercentenary Foundation, Riksbankens Jubileumsfond, see Margareta Bertilsson, Bengt Stenlund, and Francis Sejersted, Hinc robur et securitas? En forskningsstiftelses handel och vandel: Stiftelsen Riksbankens Jubileumsfond 1989-2003 (Hedemora: Gidlunds, 2004), pp. 19-30.

71 Birgitta Odén, 'Arbetsuppgifter för planering av forskningsuppgiften', March 1968, BO 1. 
had to be submitted before midsummer. ${ }^{72}$ The group took note of this, and the professors decided to write individual memoranda for the next scheduled FOA meeting on 6 May. The time frame for the programme was set at four years, starting on 1 January 1969. The grant they applied for was intended for the salaries of two to three young scholars in each of the sub-projects. In addition, the professors wanted to appoint a board consisting of the four of them, who would have funds for travel, conferences, and the purchase of books and journals. ${ }^{73}$

Birgitta Odén played a leading role in the work of the group. She was responsible for the internal communication, and she drafted the joint introduction. It is also clear that, by this time, she had made things start to happen in Lund. The economists in Stockholm and the political scientists in Umeå were still at an early planning stage. Prior to the May meeting at FOA, Odén circulated a three-page account of her activities. What is particularly interesting about this document is that the empirical exploratory drill holes she had initiated had already yielded results. Some of the young researchers had identified concrete historical problems which they wanted to investigate further.

One example of this is Lundgren's studies of the water-and-sewage question. He had investigated how the Riksdag had dealt with legislative issues regarding this matter during the early twentieth century. At that time, there was a clear conflict of interest between industry and farmers. The Conservatives sided with industry while the Liberals - supported by the Social Democrats - were on the side of those who were affected by pollutant emissions. However, when the proponents of a tougher policy gained a stronger position in the Riksdag in the 1920s, no changes occurred. Why did the activity fizzle out into passivity? The question was of general relevance, and Odén believed it deserved further investigation. Another overarching issue was responsibility for future generations. Here Sverker Oredsson's study of the nineteenth-century forest issue occupied a key position. Timber harvesting's long rotation periods led to conflicts of interest. How should economic expansion in the present be valued compared with future needs? The question also arose in discussions about another natural resource: ores. In contrast to the forests,

73 Letter from Birgitta Odén to Assar Lindbeck, 10 April 1968, BO 2. 
these resources were finite, which set the stage for interesting comparisons. ${ }^{74}$

The person who had made Birgitta Odén interested in the ore issue was the Social Democratic politician and former finance minister Ernst Wigforss. She had interviewed him in April 1968, and he had then asserted that the Conservatives and Social Democrats had reached agreement on the particular issue of ore. Both groups believed that 'ores should be exploited at this point in time - without considering the future - because people know what they can get for the ore now, whereas in the future the value could fall. ${ }^{75}$ Wigforss said that the Liberals had opposed this position and defended the right of future generations to use these resources. The conversation with Wigforss shows that Odén did not hesitate to contact politicians. The same resolve is evident in her presentation of the planned Baltic Sea project. Bo Huldt's initial studies had shown that three specific politicians of different political colours dominated the Riksdag debates. In light of this, Odén had established contacts with them for more detailed investigations. In her report to FOA, she also mentioned five student essays which she hoped would be ready by the autumn. Their stated purpose was to explore whether some key problems in Swedish environmental policy might be suitable as case studies within the broader research programme. ${ }^{76}$

The economists' memorandum was not completed until after the meeting at FOA. In a letter to Erik Dahmén dated 14 May, Odén thanks him for that memo and informs him that she will 'use the weekend to complete the introduction and then send it to you all for consideration'. ${ }^{77}$ The text Odén sent out was four pages long and she received a quick response from Back, who felt it was excellent. He had 'no amendments, not even about formal aspects' ${ }^{78}$ Lindbeck thought the introduction was 'sound' but reacted strongly against the passage where Odén described the origins of the group. The first draft stated that Martin Fehrm 'was one of the first to clearly realize the social-science side to this issue'. Lindbeck had crossed this out and written in the margin: 'Ugh! Servile!'79 Erik Dahmén's

74 Birgitta Odén, 'Redogörelse vid sammanträde på FOA 6/5', 2 May 1968, pp. $1-2$, BO 1.

75 Ibid., p. 2.

76 Ibid., p. 3.

77 Letter from Birgitta Odén to Erik Dahmén, 14 May 1968, BO 2.

78 Message from Pär-Erik Back to Birgitta Odén, 22 May 1968, BO 2.

79 Assar Lindbeck, 'Marginalkommentarer', May 1968, BO 1. 
comments were mainly about formal matters, but the changes he proposed were not insignificant. In the draft, Odén had written that the government enquiry into natural resources 'had exposed frightening perspectives' and that the subsequent environmental debate 'had assumed avalanche-like proportions'. At Dahmén's suggestion, this was changed to 'had exposed grave concerns' and 'had become very lively'. ${ }^{80}$ The changes show that Odén was strongly emotionally involved in the environmental issues, but that she was at the same time sufficiently free from prestige to change her wording. She followed Dahmén's and Lindbeck's suggested amendments at all levels.

\section{The application, the rejection, and the research group called Natur och samhälle [Nature and Society]}

On 17 June 1968, the complete application was submitted to the Bank of Sweden Tercentenary Foundation. In their preface the professors stated that, in their view, their planned research was well in line with the Foundation's stated aim of 'increasing knowledge about the effects that technological, economic, and social changes cause in society and in individuals' ${ }^{81}$ The application consisted of four parts. The first contained the joint introduction plus a description of the board's tasks and budget items. Three rather different presentations of the sub-projects followed. Whereas Odén had a detailed and reasoned text of nine pages, Back had submitted a more sketchy one of three. Thematically, however, history and political science were close to each other. What was to be examined was the political decision-making process and the role that values played in it. ${ }^{82}$

The economic project was of a different character. For Dahmén and Lindbeck, empirical studies were not enough - they aimed at theory development. The main problems to be investigated were the exploitation of natural resources, external effects, and economic planning. Their aim was to formulate a 'theory of investment in conditions of uncertainty' which assigned particular importance to 'certain special properties on the part of the relevant natural resources,

80 Erik Dahmén, 'Marginalkommentarer', May 1968, BO 1.

81 Pär-Erik Back, Erik Dahmén, Assar Lindbeck, and Birgitta Odén, 'Ansökan till stiftelsen Riksbankens Jubileumsfond om stöd till forskningsprogrammet Miljö, naturresurser och samhälle', 17 June 1968, p. 2.

82 Ibid., pp. 13-27. 
e.g. irreversibilities'. The research would be carried out in close collaboration with scientists who could help the project leaders identify suitable fields of study. The plan was five pages long, but dense in content and relatively concrete. For example, it specified which researchers were to be employed and what their qualifications were. ${ }^{83}$

However, the historical sub-project 'Natur och samhälle i svensk politik 1850-1965' [Nature and Society in Swedish politics 1850-1965] was the most developed one. Odén had built on her draft from February and now presented a coherent research plan. The introduction's presentation of the historical background and the purpose statements were basically unchanged, but the research design had been refined and streamlined. In June 1968, it was clear that the so-called 'trend studies' formed the core of the historical research programme. Now six in number, they may be roughly divided into two thematic blocks. The first one revolved around the political management of natural resources (forests, water, and ores); the second dealt with opinion formation and government-led natureconservation efforts. All the trend studies aimed to 'define the lines of reasoning - i.e. with what goal and proceeding from what value - that have been employed at various times in attempts to solve problem complexes involving nature and the environment'. This objective would be achieved by means of 'the usual historical method, expanded with the quantitative method and so-called content analysis'. Because many researchers would be investigating the same material, some centralized excerpting would be undertaken, particularly of newspaper materials. ${ }^{84}$

The second block of trend studies would examine the emergence, social composition, and ideological development of the natureconservation movement. Particular emphasis would be placed on the transition from 'aesthetically motivated nature conservation to socially and economically motivated nature conservation'. An adjoining study would explore the emergence of the governmental natureconservation administration. The last trend study, of press opinions about nature-conservation issues in the 1960s, was an 'almost self-evident part of the study', but it would not be performed until 'we have attained a better distance to the topic'. In anticipation of that stage, however, a number of exploratory student essays would be written. ${ }^{85}$

83 Ibid., pp. 29-33.

84 Ibid., p. 18.

85 Ibid., pp. 16, 17, 19. 
The trend studies that were justified in the greatest detail were the forest issue and the water-and-sewage issue. In both cases, there were obvious grounds for conflict and ideological disagreements between various groups. For that reason, the intention was for the surveys to be able to contribute general insights. The forest issue was described as an 'extremely important test instrument for ideological disagreements over natural-resource issues', and the waterand-sewage issue was 'worthy of great attention, because it exhibits several characteristic features' ${ }^{86}$ The wording shows that Odén was not looking at historically specific characteristics but pursued general conclusions. The goal was to achieve knowledge that would be applicable in the present. Consequently, it was vital to study situations and processes that resembled current ones.

In addition to the trend studies, there was a section on historical case studies. These would act as a common resource for the research programme. If the social scientists, or FOA, needed historical expertise, special interdisciplinary studies could be conducted. At the moment of writing, plans were underway for a study about the Baltic Sea and one about drainage. The case studies would adhere to a special eleven-point template that had been developed in consultation with FOA. In this way the research could be directly useful for prognostic activities. $^{87}$

In the project budget, Odén also discussed the forms of the collective research work. She stated that this work would mostly be done in the form of licentiate studies - i.e. postgraduate work for a degree level above the master's but below the doctorate - funded by scholarships. It was, however, 'necessary to attach more permanent staff to the project in order for it to be implemented in a more energetic and purposeful manner'. Odén wanted to do this by hiring a research assistant with a licentiate's degree who could be responsible for leading and planning the group's activities. This person would also write a doctoral dissertation on a topic related to the project. Furthermore, she pointed out that 'this kind of historical research requires relatively comprehensive and centralized collection work in various source compilations'. This work would be carried out by students on an hourly wage, but 'control of the excerpting and the excerpters should be the responsibility of a research assistant'. This individual would be a young researcher who would do a

86 Ibid., pp. 14-15.

87 Ibid., pp. 18-20. 
licentiate's degree within the project's framework. Odén said that suitable individuals were available at the Department of History, but she did not mention names. As access to licentiate scholarships was uncertain, she also wanted some leeway to redistribute the grant according to need. ${ }^{88}$

The historical research programme that Odén had carved out was very much a collective initiative in which young researchers would form a core. Within the space of a year, she had moved from discussing the need for social-science and historical research into environmental issues at FOA to initiating a local research environment in Lund. The close contacts with social scientists, natural scientists, politicians, and the authorities meant that the research had the potential to make its mark far outside the field of history. And then, interest in environmental issues had increased sharply in Sweden during the previous year. However, in order for her plans to be realized, funding was necessary. Her hopes were focused on the Bank of Sweden Tercentenary Foundation.

At the October 1968 meeting, however, the application was tabled. From Odén's archival papers, it appears that the Foundation was 'dissatisfied with the design of the economic and political-science sub-projects' ${ }^{89}$ However, in the early 2000s Odén personally researched the archives to find out why the application had not been approved. She discovered that the external experts had made favourable recommendations, but that the board had not followed them. She could only speculate about the reasons for this. Even so, she had a clear recollection of a brusque statement made in the autumn of 1968 by the Foundation's secretary at that time to the effect that she should not imagine 'that historians should receive money equivalent to a full-time university lecturer's position in order to study such a subject as the environment'. She describes the message as 'a slap in the face' and points out that Martin Fehrm at FOA had felt the same way: 'To some extent, of course, what was rejected was his project, his ideas. ${ }^{90}$

However, the application was tabled, not rejected; and in January 1969, Back, Dahmén, and Lindbeck submitted expanded project plans. It is apparent from these plans that the social scientists had begun doing serious work on their research ideas during the autumn

88 Ibid., pp. 20-22.

89 Letter from Pär-Erik Back to Birgitta Odén, 9 November 1968, BO 2.

90 Odén, 'Projektet Natur och samhälle', pp. 325-326. 
of 1968. Pilot studies had been implemented, and hopes for a large grant had not been dashed. Odén, however, was 'despondent after the first outcome', and she made no changes to the historical sub-project. ${ }^{91}$

At the Foundation's next meeting on 14 February 1969, the application was tabled once more. Contemporaneous letters reveal that Odén had now completely abandoned her hopes for external funding. 'This means the end of our group', she writes; 'neither Back nor Dahmén can hold their groups together after a year of promises social scientists are in demand and cannot be expected to live on air.' The young researchers in Lund were 'steadfast', but Odén doubted her own role and future. 'How long will I be able to carry the load without any help in the form of a secretary or assistant?' She announced that she would scale down her activities to a low level, thereby avoiding 'any obligation to deliver anything'. ${ }^{92}$

An unexpected decision was announced in mid-April 1969. The Bank of Sweden Tercentenary Foundation had decided to provide funding for the economic part of the project. That announcement simultaneously meant the definite end of the group's joint venture. FOA submitted a letter of protest, but Back and Odén were not prepared to fight on. ${ }^{93}$ Still, Odén was anxious that the environmentalhistory initiative in Lund should not go to waste. She felt that some form of continuation was necessary, especially in view of the young researchers she had involved. In consultation with Sverker Oredsson, she concluded that the research group 'Natur och samhälle' should be formed. However, she herself took a step back and handed over the leadership to Oredsson. During the early 1970s, the group met regularly about once a month; but this was not a coordinated research programme. The dissertation topics were rather diverse, and the group members' working conditions varied widely. Only Lars J. Lundgren and Rune Ivarsson did full-time research. In 1974, Sverker Oredsson left the research field in order to take on assignments in municipal politics. ${ }^{94}$

The circumstances of Birgitta Odén's relinquishing of the natureand-society project are not entirely easy to explain. From the archival

91 Ibid., p. 326.

92 Letter from Birgitta Odén to Jan Zeilon, 18 February 1969, BO 2.

93 Letter from Carl Gustav Jennergren to Birgitta Odén, 13 May 1969, BO 2.

94 Birgitta Odén, 'Rapport', 8 January 1970, BO 2. Interview with Lars J. Lundgren, 18 September 2017. Interview with Sverker Oredsson, 14 December 2017. 
material, as well as from my interviews, it appears that she continued to be very interested in environmental issues and environmental history. It was not until the 1980s that she seriously tackled the issue again, though, and then it was from a didactic perspective. Later, she also participated in the environmental-history conferences that began to be held in Sweden in the 1990s. Lars J. Lundgren especially remembers a speech she gave at a conference dinner in the early 2000s, a speech in the course of which she looked back at her early research ideas and described her decision to switch topics in drastic terms: 'I dropped out of the group. It was better to hand it over to someone else. Because I had failed so badly and been declared an idiot.' The strong words made an impression on Lundgren, who only then realized how hard Odén had taken the rejection. Some time after the conference, he therefore asked her to expand on her thoughts, and she told him: 'I was young, I was new, and I wanted to invest my energy in a new field.' The negative decision had been too much: 'I couldn't handle it.' ${ }^{95}$

Odén's powerful feelings also emerge in a backward look at the project which she wrote in 2002. The text proudly states that Per Eliasson had just successfully defended 'a forest-history dissertation within the field of history, employing patent interdisciplinary approaches'. The dissertation signified that 'the ignominy from 1968/69 was washed away' and that 'environmental history in its Lundian, politicized form' could confidently proceed. Odén added: 'Ideas can be impeded by a lack of resources. But they do not have to die. They can return with new bearers and be stimulated by new impulses from the many disciplines that have the environment on their agenda. ${ }^{96}$ The venture had not been in vain.

\section{Knowledge actors and networks}

The histories of Barbro Soller and Birgitta Odén give us a deeper understanding of how the breakthrough of environmental issues in Sweden happened. Their professional commitment underlines that the social knowledge breakthrough involved and activated many different types of knowledge actors. In Soller's case, her interest in environmental and nature issues was accentuated. Over the course of the 1960s, she increasingly became a driver of

95 Interview with Lars J. Lundgren, 18 September 2017.

96 Odén, 'Projektet Natur och samhälle', p. 332. 
the development. At times it was she who set the agenda of the Swedish environmental debate. In Odén's case, the breakthrough of environmental issues led to a radical reorientation of her own research - from sixteenth-century nation-state finances to modern industrial society's interaction with nature. By adopting this approach, she attempted to bring the field of history closer to the present day and to make it practically useful in social planning. However, these great ambitions did not materialize. Her own career took other paths.

Even so, Odén's environmental-historical initiative was not without results. Several of the students and young researchers she recruited would continue down the route she had staked out. This was particularly true of Lars J. Lundgren, who defended his dissertation 'Vattenförorening i Sverige 1890-1921' [Water pollution in Sweden 1890-1921] in 1974. It was followed by a long career at the National Environment Protection Board, a career which was combined with writing about environmental history. That would not have happened without Odén. This example underlines the fact that a social knowledge breakthrough is not an abstract phenomenon. A highly concrete historical process, it entails people trying new things, which then leads other people to do new things. Chains of events and lives intersect. No one is an island.

In this context, the extensive personal networks to which knowledge actors belong play a decisive role. Tracing the paths of Soller and Odén has enabled some of these networks to become visible. The two women's good relations with scientific researchers were particularly important. Soller was highly trusted as a conveyor of new discoveries. For the mercury researcher Stig Tejning, she almost served as a mouthpiece. With Soller's help, his pilot studies and experiments became front-page news, which was important in securing large research grants. Birgitta Odén's most important relationship was with her brother, Svante. He was a direct link to the research front, and he was also present at the meetings at FOA. The social knowledge breakthrough occurred in and through this type of network. In 1960s Sweden, science, politics, and the media were closely intertwined. Historical actors who understood how to take advantage of that could make a lot happen.

The clearest example of this is Hans Palmstierna. In this chapter, as in the previous ones, we have seen how his name appeared in all kinds of contexts. Palmstierna's wide-ranging social contacts are seen in his extensive private correspondence as well. After the great breakthrough in the autumn of 1967, people from all over the 
country, with various backgrounds and jobs, wrote to him. I have singled out a few individual examples, such as the author Sven Fagerberg and the layman Sören Gunnarsson. The next chapter applies a comprehensive approach to Hans Palmstierna's preserved correspondence as a whole, with a view to presenting a clear picture of the Swedish society in which the breakthrough of environmental issues occurred. What did people who became aware of the environmental issues actually do? Along what lines did they think about their new insights? And on what sorts of issues did they consult the foremost environmental debater in the country? 